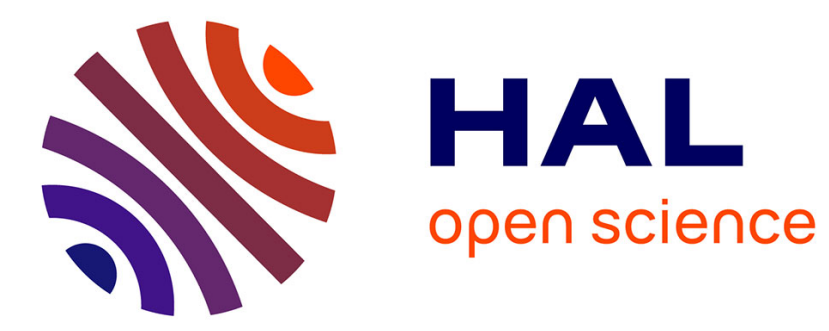

\title{
Poverty among minorities in the United States: Explaining the racial poverty gap for Blacks and Latinos \\ Carlos Gradín
}

\section{To cite this version:}

Carlos Gradín. Poverty among minorities in the United States: Explaining the racial poverty gap for Blacks and Latinos. Applied Economics, 2011, pp.1. 10.1080/00036846.2011.581219 . hal-00712378

\section{HAL Id: hal-00712378 \\ https://hal.science/hal-00712378}

Submitted on 27 Jun 2012

HAL is a multi-disciplinary open access archive for the deposit and dissemination of scientific research documents, whether they are published or not. The documents may come from teaching and research institutions in France or abroad, or from public or private research centers.
L'archive ouverte pluridisciplinaire HAL, est destinée au dépôt et à la diffusion de documents scientifiques de niveau recherche, publiés ou non, émanant des établissements d'enseignement et de recherche français ou étrangers, des laboratoires publics ou privés. 


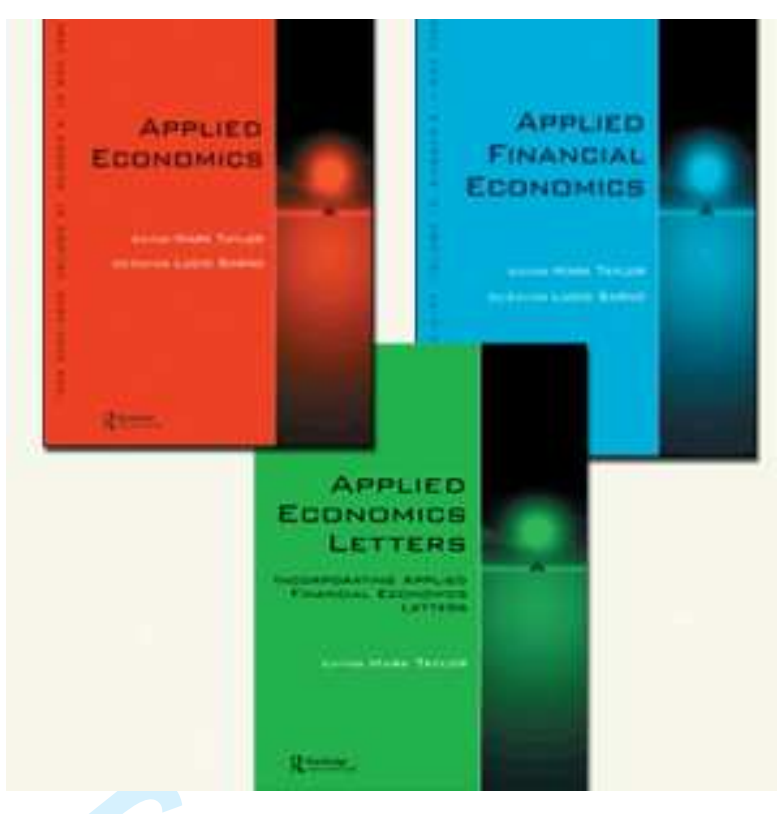

\section{Poverty among minorities in the United States: Explaining the racial poverty gap for Blacks and Latinos}

\begin{tabular}{|r|l|}
\hline Journal: & Applied Economics \\
\hline Manuscript ID: & APE-2010-0204.R1 \\
\hline Journal Selection: & Applied Economics \\
\hline Date Submitted by the \\
Author: & 27-Sep-2010 \\
\hline JEmplete List of Authors: & Gradín, Carlos; Universidade de Vigo \\
\hline & $\begin{array}{l}\text { D31 - Personal Income, Wealth, and Their Distributions < D3 - } \\
\text { Distribution < D - Microeconomics, D63 - Equity, Justice, } \\
\text { Inequality, etc. and Measurement < D6 - Welfare Economics < D - } \\
\text { Microeconomics, I32 - Measurement and Analysis of Poverty < I3 - } \\
\text { Welfare and Poverty < I - Health, Education, and Welfare, J15 - } \\
\text { Economics of Minorities and Races < J1 - Demographic Economics } \\
<\text { J - Labor and Demographic Economics }\end{array}$ \\
\hline \hline Keywords: & poverty differential, minorities, United States, decomposition \\
\hline \multicolumn{2}{|l}{} \\
\hline
\end{tabular}

\section{SCHOLARONE ${ }^{\text {m }}$ \\ Manuscripts}




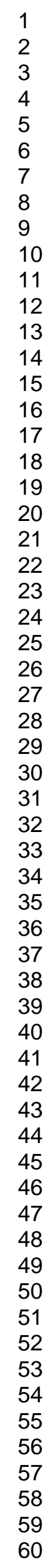

14

15

16

18

19

20

22

24

26

27

29

30

32

33

34

35

36

39

40

41

42

44

45

46

47

48

49

50

52

53

54

55

57

58

59

60

Editorial Office, Dept of Economics, Warwick University, Coventry CV4 7AL, UK 


\title{
Poverty among minorities in the United States:
}

\section{Explaining the racial poverty gap for Blacks and Latinos}

\author{
Carlos Gradín* \\ Universidade de Vigo
}

\begin{abstract}
The two largest minorities in the United States, African Americans and people of Hispanic origin, show official poverty rates at least twice as high as those of non-Hispanic Whites. These similarly high poverty rates between the two minorities are, however, the result of different combinations of factors related to the specific characteristics of these two groups. In this paper, we analyze the role of demographic and labor-related variables in the current differential of poverty rates among racial and ethnic groups in the United States and its recent evolution. Our results show, first, that these differentials are largely explained by differing family characteristics of the ethnic groups. Furthermore, we show that while labor market activity of family members and a preponderance of single mothers play a more significant role in the higher poverty rates of Blacks, a larger number of dependent children is closely associated with higher poverty among Latinos, who also suffer from a larger educational attainment gap and higher immigration rates.
\end{abstract}

JEL Classification: D31, D63, 132, J15, J82

Keywords: poverty, gap, race, decomposition, Oaxaca-Blinder, United States, CPS, labor market, participation, education, family characteristics.

* Address for correspondence: Facultade de CC. Económicas, Universidade de Vigo, Campus LagoasMarcosende s/n, 36.310 Vigo, Spain. Email: cgradin@uvigo.es 


\section{Introduction}

Most ethnic minorities in the United States have historically shown low performance in a number of socioeconomic indicators when compared with majority non-Hispanic Whites. Their share of the population is increasing, so that nowadays more than one in four Americans belong to one of the two largest minorities, Blacks and Latinos. But the median per capita family income for these two groups is below 60 percent of levels for non-Hispanic Whites, and their poverty rate is at least twice as high. These minorities, which constitute half of all poor Americans, share similar socioeconomic and demographic patterns of deprivation in several other dimensions: they have less education, less health insurance coverage, and a larger risk of being prison inmates, unemployed, or low-paid workers. ${ }^{1}$ Furthermore, they share several demographic characteristics typically associated with disadvantaged groups, including more dependent children in their families and a larger share of female-headed families, especially single mothers; however, both minorities also differ in a number of relevant aspects.

Non-Hispanic Blacks account for a steady 13 percent of the overall population. Only 8 percent of them are foreign born, compared with 13 percent of the overall population. Blacks appear to have a larger incarceration rate than any other group, as well as a larger proportion of female-headed families and of young males out of work. It is a well-known fact that almost 70 percent of all Black children are born to unmarried mothers (US DHHS, 2004) and, consequently, about half of all Black children live with a single mother. Additionally, more than 11 percent of Black males aged 25 to 34 were incarcerated as of June 2006 (US DJOJP, 2007). Indeed, it comes as no surprise that these factors appear among the most common explanations for their higher poverty rates.

On the other side, most Hispanics are immigrants who arrived in the United States after the 1980s from Latin America, especially Mexico, settling in the southern and eastern portions of the country. As a consequence of rapid population growth, the number of Latinos grew from 10 million to 45 million between 1970 and 2007 (from 5 to 15 percent of the total population), recently becoming the largest minority group in the country, with a population still growing

\footnotetext{
${ }^{1}$ As a matter of fact, 20 percent of Blacks and 34 percent of Hispanics had no health insurance in 2007, compared with 11 percent of non-Hispanic Whites (US CB, 2007). According to our own estimations, unemployment rates in the same year were respectively 8.4 and 5.7 percent of the active population, compared with 4 percent of Whites, and 19 and 13 percent respectively of Black and Latino adults older than 25 went to college compared with 32 percent of Whites. An estimated 4.8 percent of Black men were in prison or jail in midyear 2006, compared with 1.9 percent of Hispanic men and 0.7 percent of White men (US DJOJP 2007).
} 
faster than that of any other ethnic group. ${ }^{2}$ The result of this recent migration process is that two in five Latinos are foreign born, and they have a higher fertility rate and a larger educational gap than any other group.

In this paper, we aim to identify the nature of higher poverty rates among African Americans and Latinos in the United States, and to assess to what extent they are associated with the poor endowments of these groups in terms of demographic characteristics, educational attainment, and labor market performance. Alternatively, higher poverty rates may be the result of these characteristics being less effective for pushing their families above the poverty line. Furthermore, we want to identify how the distinct features of Blacks and Latinos affect their poverty risks in different ways. To answer these questions, we estimated logit poverty regressions and used an Oaxaca-Blinder approach adapted to this specific framework to decompose the racial difference in poverty rates into characteristics and coefficient effects. This decomposition was conducted at two different levels: at the aggregate level, we estimated the joint contribution of all characteristics and all coefficients respectively, whereas at the detailed level we identified the individual contributions of each set of characteristics.

The structure of the paper is as follows. We first describe the data and main definitions, then review and compare the main socioeconomic patterns of racial groups in the United States. After this, we introduce the decomposition technique and present our empirical results. The final section summarizes our main conclusions.

\section{Data and some definitions}

The data used in the main analysis were taken from the Current Population Survey, 2007 Annual Social and Economic (ASEC) March Supplement, conducted by the U.S. Census Bureau. ${ }^{3}$ The 1994 and 2002 surveys will also be used for the analysis of time trends. This data source provides comprehensive monthly labor force data for persons 15 years old and over, as well as the main characteristics of families. While demographic data refer to the time of the survey, data on employment and income refer to the preceding year. ${ }^{4}$

\footnotetext{
${ }^{2}$ The U.S. Bureau of Census estimated a growth of 24 percent for the Hispanic population between 2000 and 2006 (compared with 6 percent for the overall population), with a projection of 102.6 million Latinos by 2050, nearly a quarter of the entire population (US CB, 2008).

${ }^{3}$ The universe of this survey was the civilian noninstitutional population of the United States living in housing units, and members of the armed forces living in civilian housing units on a military base or in a household not on a military base.

${ }^{4}$ To be consistent with Census Bureau publications, our income and poverty estimates refer to the year in which income was obtained, with characteristics as of March of the following year (the survey's year).
} 
In this survey, people are asked to answer questions about their race and Hispanic origin. Since 2003 , respondents have been allowed to report more than one race, selecting from six distinct race groups. Further, this survey inquires whether the origin of each person is Spanish, Hispanic, or Latino. On the basis of these questions, we distinguish three nonoverlapping groups in the population: non-Hispanic Whites (those who declared only this race), nonHispanic Blacks or African Americans (identifying themselves as non-Hispanic and Black, either alone or in combination with other races), Hispanics or Latinos (of any race). ${ }^{5}$ The 2007 sample includes 190,818 observations. ${ }^{6}$

The definition of poverty used in this paper corresponds to the official poverty definition employed by the U.S. Census Bureau following Statistical Policy Directive 14 of the Office of Management and Budget (OMB) (May 1978). It comprises a set of income thresholds that vary by family size and composition to determine who is in poverty. If a family's total income is less than that family's threshold, then that family and every individual in it is considered to live in poverty. The official poverty definition uses money income before taxes, and does not include capital gains or noncash benefits. ${ }^{7}$ These thresholds are updated annually for inflation using the Consumer Price Index (CPI-U).

\section{Racial poverty profiles in the United States}

Persistence of high poverty rates in the United States, with levels higher than those of the majority of the developed world, has been so far well documented, as well as the fact that the distribution of income has become more unequal and polarized. Additionally, there is a large differential in well-being across U.S. ethnic and racial groups, as well as increasing racial polarization resulting from the growing proportion of American minorities at the bottom of U.S. income distribution. On average, Black and Latino minorities are poorer than Whites in the

\footnotetext{
${ }^{5}$ For the sake of simplicity in what follows, we will refer to Blacks or Whites while omitting their "nonHispanic" origin.

${ }^{6}$ Of which 132,853 are Whites, 34,125 Hispanics, and 23,840 Blacks. The total sample size for 1994 was 144,010, and for $2002203,233$.

${ }^{7}$ These absolute poverty thresholds were formulated in the mid 1960's, with only minor adjustments since then, and have been widely criticized not only for the limited notion of income used, but also because they have not reflected any changes in lifestyle or in consumption standards since they were established. However, they still constitute the main reference for all poverty analysis in the United States. For 2006 , these limits were $\$ 10,488$ for one person under 65 years old and $\$ 20,444$ for a family of two adults with two related children under 18 .
} 
United States: 24.3 and 20.8 percent of their respective populations, 2.5 to 3 times more than among Whites (8.3 percent) in $2006 .^{8}$

What are the reasons for these differences in poverty rates among racial and ethnic groups? Obviously, they may be the result of specific characteristics of the families in which they live. Clearly, these differentials can be explained to some extent by the fact that minorities are more likely to live in the poorest areas, have more children, live in single-mother families, work fewer hours, and be employed in low-paid occupations. Let us briefly review some of these differences in the relevant attributes.

First, ethnic minorities are unevenly distributed across the U.S. geography and are overrepresented in regions with the highest poverty levels, even if this is not expected to substantially increase their poverty risk due to the low range of variation of poverty across regions in the United States. ${ }^{9}$ Furthermore, these minorities are more likely to live in the largest metropolitan areas (more than 2.5 million inhabitants) than in non-metropolitan areas, which actually had the highest poverty rates. ${ }^{10}$

Blacks and Latinos are also characterized by different living arrangements from those of Whites, and this is expected to affect their higher poverty rates. Both populations were less likely to live in married-couple families in 2007: 62 percent of Hispanics and only 40 percent of Blacks, compared with 68 percent of Whites; only 6 percent of those living in this type of family were poor in 2006. On the contrary, Blacks were more likely to live in a female-headed family without a spouse present (45 percent) than the other main groups (20 percent among Whites and 24 for Latinos). The single-female type of family faced a poverty risk 10 percentage points higher than that of male-headed families without a spouse present. More specifically, minorities also had a larger share of people living in single-mother families: 15.6 percent among Hispanics and 26.5 among Blacks, compared with only 6.6 among Whites. ${ }^{11}$ These families' reported poverty rate was higher than that for any other type (38 percent).

\footnotetext{
${ }^{8}$ Examples of recent detailed analysis of poverty in the United States are Iceland (2006) and Rodgers (2006).

${ }_{9}$ Indeed, both minorities were more likely to live in the south-central eastern region, where the poverty rate was 16 percent in 2006, and Hispanics were also more likely to live in the south-central western region, where the poverty rate was 17 percent. However, most Hispanics and Blacks actually lived in regions with poverty rates between 10 and 12 percent.

${ }^{10}$ Note, however, that we cannot here consider the effect on poverty caused by residential segregation within metropolitan areas, with minorities living in poor inner cities and Whites in rich suburbs.

${ }^{11}$ There is no consensus about the causes of change in marriage, divorce, and nonmarital childbearing that occurred during past decades leading to this situation. Changes in social norms, declining wages among low-skilled men, and the unintended incentives of the welfare system have been pointed out as possible explanations (MacLanahan, 2007).
} 
Furthermore, Latinos, and to a lesser extent Blacks, are more likely to have larger families: their families had 3.5 members on average in 2007 (compared with 3.0 in the case of Blacks and 2.9 of Whites), with more dependents of all ages among them, but especially children (1.25 compared with 1 and 0.76 , respectively). As a consequence, 43 percent of Hispanic family members were economically dependent, compared with 38 percent among Blacks and only 25 percent among Whites.

Poverty risk among people in families headed by a non-American citizen was 22 percent, twice as high as in the other cases, including those headed by either naturalized foreign-born or second-generation immigrants. This appears to be particularly relevant for the Hispanic population, given that 40 percent lived in a family with a foreign head, compared with only 2 percent of Whites and 5 percent of Blacks. Family heads, and the general population, tend to be younger among Hispanics and Blacks than among Whites, and this is another factor that might increase the poverty levels of minorities, considering that poverty risk declines with the age of the family head, and was especially high for young-headed families (32 percent were poor when the head was younger than 24); this group comprised 10 percent of Hispanics, 8 percent of Blacks, and only 5 percent of Whites. Another characteristic that is clearly distinctive of minorities is their level of attained education. Only 11 percent of Hispanic family reference persons went to college, compared with 18 percent of Blacks and 33 percent of Whites. A similar gap was found among the population as a whole.

\section{Labor Market performance}

Labor market performance varies greatly across ethnic and racial subpopulations. Latinos and Whites participate in the labor market at a higher rate than Blacks. The employment rate of Hispanic and White adults (15 years or older) was 63 and 62 percent, respectively, in 2006, compared with 57 percent of Blacks; however, these aggregate figures conceal several specific features of each group. Hispanic males had the largest employment rates: 74 percent compared with 68 percent of Whites and 57 percent of Blacks; whereas Hispanic females, on the contrary, had the lowest employment rate, 52 percent compared with about 56 percent of Black and White females. ${ }^{12}$ Further, there was substantial occupational segregation by ethnic group in the labor market, and Whites were more likely than any other group to work in

\footnotetext{
${ }^{12}$ The high employment rate of Hispanic males was intimately related to their large immigration rate. Indeed, the employment rate of Hispanic males born in a foreign country was 88 percent, in contrast with 71 percent of those born in the United States, similar to the 73 percent of non-Hispanic White males in the same situation.
} 
managerial and professional jobs in the private sector or to be self-employed. ${ }^{13}$ Despite a lack of significant difference in the average number of hours and weeks worked by employed adults, the earnings of Black and Hispanic workers were, respectively, 70 and 65 percent of those of Whites. ${ }^{14}$

During the economic expansion of the 1990s, the employment rate of those not enrolled in higher education increased in the case of Blacks and Latinos (but not of Whites) for most subgroups according to gender, age, and education; however, the increase was especially marked for females below the age of 55 with no college studies, amounting to between 7 and 12 percentage points, depending on age and minority. The 2000s did not significantly reverse these improvements. The fact that the employment rates of low-educated young Black males did not significantly advance during the last economic booms has been a major academic issue to date. Among the possible explanations for this phenomenon, direct and indirect consequences of large and increasing incarceration rates (even in a context of decreasing criminality) and the migration of jobs from inner cities to suburbs have been mentioned. ${ }^{15}$

Another remarkable feature of labor force participation expected to have an impact on poverty is the dramatic increase in employment rates for single mothers during the economic boom of the 1990s. This was especially important for Blacks and Hispanics, as they showed, respectively, 14 and 22 percentage-point increases. This unprecedented shift to work was the result of drastic changes in economic incentives faced after the mid-1990s by welfare beneficiaries, mainly single mothers, combined with a strong economic boom that allowed welfare reform to be implemented thanks to low unemployment and readily available jobs (Blank, 2002). ${ }^{16}$

\footnotetext{
${ }^{13}$ Note also that Blacks were more likely than Hispanics to work in skilled jobs or in the public sector, as well as to be unemployed, but less likely to be self-employed.

${ }^{14}$ Several reasons, including wage discrimination, have been given for these racial and ethnic gaps in earnings. For example, Antecol and Bedard (2004) emphasized the role of labor market attachment differences among young males, while Carneiro, Heckman, and Masterov (2005) argued that the major source of economic disparity by race and ethnicity in U.S. labor markets was to be found in pre-labor factors.

${ }^{15}$ For example Holzer, Raphael, and Stoll (2006) argued that the high rates of crime and incarceration among young Black males limited employment opportunities not only of those directly engaged in such behavior, but also of those not engaged in crime as a result of statistical discrimination by employers. Further, Foster-Bey (2006) found evidence that spatial mismatch in the blue-collar sector affected labor participation of young males residing in the urban core of metropolitan areas.

${ }^{16}$ In particular, as the result of reforms of social assistance programs through the 1996 Personal Responsibility and Work Opportunity Act and increases in the Earned Income Tax Credit and minimum wage, "cash assistance became far less available, welfare recipients were pushed much harder to employment and leave the rolls, the returns to low-wage work rose, and the availability of work supports (child care and health insurance) increased to low-income families" (Blank, 2002, page 1108).
} 


\section{Methodology}

We examined the contribution of a number of family characteristics to the differential in poverty rates among racial groups in the United States by applying an extension of the wellknown regression-based Oaxaca-Blinder decomposition approach to the probability of being poor. ${ }^{17}$ In our framework, the ith person in group $g$ is considered poor when his or her family income $y_{i}^{g}$ falls below poverty line $z$. Then, in a logit probability model, the likelihood of this person being poor $\left(P_{i}^{g}\right)$ is given by

$$
P_{i}^{g}=\operatorname{Pr}\left(y_{i}^{g}<z\right)=F\left(X_{i}^{g} \hat{\beta}^{g}\right)=\frac{\exp \left(X_{i}^{g} \hat{\beta}^{g}\right)}{1+\exp \left(X_{i}^{g} \hat{\beta}^{g}\right)^{\prime}}
$$

where $F$ represents the logistic probabilistic cumulative distribution, $X_{i}^{g}$ is a vector of characteristics describing i's family, and $\hat{\beta}^{g}$ is the associated vector of coefficient estimates. We estimated regressions separately for Whites, Blacks, and Hispanics.

Given that being officially poor means that a family lacks sufficient income to make ends meet, we included among the explanatory variables a number of characteristics of the family reference person that might influence his or her ability to earn income: demographic variables such as gender, age, attained education (primary, secondary, or college), citizenship (native with/without foreign-born parents, foreign-born naturalized, or not naturalized), and mover status (change of residence in the previous year), as well as a set of variables describing labor force participation of the head and, in the case of those employed, characteristics of the job. ${ }^{18}$ We also included the type of family, as this can also affect the ability of the family head to get a job. ${ }^{19}$ Given that family income can also be provided by other family members and that the presence of dependents can increase family needs but not income, we included the number of other family members as well. ${ }^{20}$ Other variables included were the geographic region of

\footnotetext{
${ }^{17}$ See Oaxaca (1973) and Blinder (1973).

${ }^{18}$ These variables included several types of occupation according to the sector (private or public), contract (part- or full-time), required skills (managerial/professional occupation or not), employment status (self-employed or employee), and the number of weeks and average weekly hours worked.

${ }^{19}$ We distinguished among families composed of a married couple, with additional distinction according to the sex of the head, and those composed by a male or a female without a spouse present. In the case of female heads, we additionally distinguished whether children were present in order to identify single mothers, with an interaction variable indicating their employment status.

${ }^{20}$ We distinguished the number of dependents (of different ages) from the number of labor and nonlabor income receivers (by education attained and gender, and, in the case of employed, also by age and characteristics of the job).
} 
residence and the size of the metropolitan area, to take into account potential differences in economic opportunities.

We estimated the probability of a person being poor with all explanatory variables collected at the family level. ${ }^{21}$ As a consequence of this specification, the standard i.i.d. assumption is violated due to correlation within families (clusters). For this reason, following Cappellari and Jenkins (2004), we computed robust variance estimators, allowing for arbitrary correlation between observations within the same sample cluster, while assuming independence across clusters.

This simple econometric specification allowed us to identify the statistical association between the probability of being poor and each family attribute when the other characteristics are controlled for; however, we should be cautious in interpreting the results, as no control for possible endogeneity sources was made, and no causal relationship can be assessed. ${ }^{22}$

An interesting property of the logit specification in our framework is that the head-count ratio of poverty in group $g, H^{g}$, is equal to the average predicted probability for this group (with population $N^{g}$ ):

$$
H^{g}=\overline{P^{g}}=\overline{F\left(X_{i}^{g} \hat{\beta}^{g}\right)}=\frac{1}{N^{g}} \sum_{i=1}^{N^{g}} F\left(X_{i}^{g} \hat{\beta}^{g}\right) .
$$

This property allows us to use the average estimated probabilities to break the observed differential in poverty rates among two given groups 0 (Whites) and 1 (Blacks or Hispanics),

$$
H^{1}-H^{0}=\overline{P^{1}}-\overline{P^{0}}=\overline{F\left(X^{1} \beta^{1}\right)}-\overline{F\left(X^{0} \beta^{0}\right)}
$$

into two distinct terms, when the characteristics of group 0 are taken as reference: ${ }^{23}$

\footnotetext{
${ }^{21}$ In other words, each family is replicated $m$ times in the regression, where $m$ is the family size. The reason for this is that poverty is usually measured as the proportion of individuals (not families) below the poverty line, while the poverty status of any person is determined according to his or her family income.

${ }^{22}$ For example, consider the potential double causality in the case of the number of dependent children in the family. A large number of children directly affects the probability of being poor by increasing family needs (through the official poverty line) while not providing additional income. However, this characteristic can also be interpreted as a consequence of living in a poor, less-educated family.

${ }^{23}$ This way, the same reference group is considered in the analysis of Blacks' and Latinos' differentials in poverty. From a theoretical point of view, the alternative reference group (the minority) might also be considered, providing similar results to those presented in the empirical sections. Note, however, that improving the characteristics of poor minorities so they converge with the affluent majoritarian Whites seems a more plausible political aim than the alternative of equalizing groups by worsening Whites' endowments.
} 
The first term is the aggregate characteristics effect, and the second one is the aggregate coefficients effect.

To evaluate the individual contribution of each variable (or set of variables) to the total explained difference, which is usually referred to as the detailed decomposition, we followed the linearized method proposed by Even and Macpherson (1990, 1993) and Yun (2004). The detailed decomposition of the characteristics effect for any nonlinear function $F$ is given by

$$
\overline{F\left(X^{1} \beta^{1}\right)}-\overline{F\left(X^{0} \beta^{1}\right)}=\sum_{k=1}^{K} W_{\Delta X}^{k}\left[\overline{F\left(X^{1} \beta^{1}\right)}-\overline{F\left(X^{0} \beta^{1}\right)}\right],
$$

where $W_{\Delta X}^{k}$ is the individual relative contributions of characteristic $k(k=1, \ldots, K)$ to the overall characteristics effect such that:

$$
W_{\Delta X}^{k}=\frac{\left(\bar{X}_{k}^{1}-\bar{X}_{k}^{0}\right) \beta_{k}^{1}}{\left(\bar{X}^{1}-\bar{X}^{0}\right) \beta^{1}}, \sum_{k=1}^{K} W_{\Delta X}^{k}=1
$$

This technique has a few advantages over other proposed methods that appear in the literature. First, the weights are quite transparent and simple to compute, because only estimates of the coefficients and sample means for the characteristics are required. Second, this procedure overrides the problem of path dependency common to all sequential approaches to nonlinear models, in which values of characteristics and/or coefficients of one group need to be switched with those of the other group. Third, unlike these sequential approaches, the detailed characteristics effect can be obtained without matching individuals of one group with the characteristics of another. Additionally, the original Oaxaca-Blinder approach is shown to be a particular case of this decomposition when $F$ is a linear function. Finally, standard errors will be provided following the Delta method sketched in Yun (2005).

\section{Explaining the racial poverty gap}

The analysis of decomposition of the racial poverty gap is based on the estimation of multivariate logit regressions explaining the likelihood of a person being poor conditioned by 
family characteristics. ${ }^{24}$ Poverty rates among Blacks were 15.9 percentage points higher than among Whites in 2006, and the decomposition analysis of this differential, presented in Table 2, shows that this can largely be explained by the characteristics effect. That is, 12.2 percentage points (76.6 percent) of this raw racial poverty gap for Blacks can be attributed to differences in the observed family characteristics of both groups. Despite the fact that observed characteristics explain a large share of the racial poverty gap for Blacks and Latinos, our results also suggest that the impact of certain attributes on poverty risk might be different for these groups compared with Whites. The aggregate coefficient effect is in all cases significant ${ }^{25}$. As a result, the conditional racial poverty gap-that prevailing if Blacks shared the characteristics of Whites-was 3.7 percentage points (the remaining 23.4 percent of the gap). Now we discuss in more detail the main factors explaining the poverty gap (detailed characteristics effect).

\footnotetext{
${ }^{24}$ The results for all racial and ethnic groups using the 2007 surveys (with results referring to poverty in 2006) are presented in the Appendix. In general, these results suggest that the coefficients are similar in sign for all groups, although they may differ in magnitude and statistical significance.

${ }^{25}$ However, most of the detailed effects of grouped variables, not discussed here, are not. One important exception is the number of hours worked by Hispanic family heads, which was less effective than those worked by Whites in protecting their respective families from being poor, as it explained about 1.6 percentage points of the raw gap in poverty rates (13 percent of the gap). See Gradín (2008) for details.
} 
Table 1 Decomposition of the racial poverty gap, 2006

\begin{tabular}{|c|c|c|c|c|}
\hline & Blacks & $\%$ & Hispanics & $\%$ \\
\hline RAW GAP & $\begin{array}{r}15.9 \\
(0.23)\end{array}$ & 100 & $\begin{array}{r}12.5 \\
(0.37)\end{array}$ & 100 \\
\hline AGGREGATE COEFFICIENTS EFFECT & $\begin{array}{r}3.7 \\
(0.40)\end{array}$ & 23.4 & $\begin{array}{r}3.0 \\
(0.51)\end{array}$ & 24.0 \\
\hline $\begin{array}{l}\text { AGGREGATE CHARACTERISTICS EFFECT } \\
\text { DETAILED: }\end{array}$ & $\begin{array}{r}12.2 \\
(0.39)\end{array}$ & 76.6 & $\begin{array}{r}9.5 \\
(0.54)\end{array}$ & 76.0 \\
\hline 1. Geographic & $\begin{array}{r}-0.1 \\
(0.31)\end{array}$ & -0.6 & $\begin{array}{r}-0.4 \\
(0.34)\end{array}$ & -2.9 \\
\hline 1.1 State & $\begin{array}{r}0.4 \\
(0.22)\end{array}$ & 2.5 & $\begin{array}{r}0.0 \\
(0.28)\end{array}$ & 0.0 \\
\hline 1.2 Metropolitan area size & $\begin{array}{r}-0.5 \\
(0.18)\end{array}$ & -3.0 & $\begin{array}{r}-0.4 \\
(0.24)\end{array}$ & -2.9 \\
\hline 2. Sociodemographic & $\begin{array}{r}5.6 \\
(0.50)\end{array}$ & 35.3 & $\begin{array}{r}6.5 \\
(0.58)\end{array}$ & 51.9 \\
\hline 2.1 Family type & $\begin{array}{r}1.8 \\
(0.45)\end{array}$ & 11.2 & $\begin{array}{r}0.4 \\
(0.13)\end{array}$ & 3.2 \\
\hline 2.2 Mobility & $\begin{array}{r}0.4 \\
(0.15)\end{array}$ & 2.4 & $\begin{array}{r}1.9 \\
(0.52)\end{array}$ & 15.1 \\
\hline 2.3 Age of head & $\begin{array}{r}1.1 \\
(0.11)\end{array}$ & 7.0 & $\begin{array}{r}0.9 \\
(0.18)\end{array}$ & 7.1 \\
\hline 2.4 Dependents & $\begin{array}{r}2.3 \\
(0.19) \\
\end{array}$ & 14.7 & $\begin{array}{r}3.3 \\
(0.28) \\
\end{array}$ & 26.5 \\
\hline 2.4.1 Aged 0-15 years & $\begin{array}{r}2.1 \\
(0.19)\end{array}$ & 13.5 & $\begin{array}{r}3.1 \\
(0.27)\end{array}$ & 25.0 \\
\hline 2.4.2 Aged $16-45$ years & $\begin{array}{r}0.1 \\
(0.02)\end{array}$ & 0.9 & $\begin{array}{r}0.2 \\
(0.04)\end{array}$ & 1.3 \\
\hline 2.4.3 Aged $46+$ years & $\begin{array}{r}0.1 \\
(0.01) \\
\end{array}$ & 0.4 & $\begin{array}{r}0.0 \\
(0.02) \\
\end{array}$ & 0.2 \\
\hline 3. Education and labor activity & $\begin{array}{r}6.0 \\
(0.38)\end{array}$ & 37.6 & $\begin{array}{r}2.5 \\
(0.40)\end{array}$ & 19.9 \\
\hline 3.1. Family Head & $\begin{array}{r}2.3 \\
(0.38) \\
\end{array}$ & 14.4 & $\begin{array}{r}2.6 \\
(0.33) \\
\end{array}$ & 20.9 \\
\hline 3.1.1 Education of head & $\begin{array}{r}0.9 \\
(0.12)\end{array}$ & 5.5 & $\begin{array}{r}2.2 \\
(0.29)\end{array}$ & 17.8 \\
\hline 3.1.2 Labor activity of head & $\begin{array}{r}1.4 \\
(0.37)\end{array}$ & 8.9 & $\begin{array}{r}0.4 \\
(0.24) \\
\end{array}$ & 3.1 \\
\hline 3.1.2.a Inactive & $\begin{array}{r}0.0 \\
(0.01)\end{array}$ & -0.1 & $\begin{array}{r}0.0 \\
(0.04)\end{array}$ & 0.0 \\
\hline 3.1.2.b Unemployed & $\begin{array}{r}0.2 \\
(0.05)\end{array}$ & 1.2 & $\begin{array}{r}0.1 \\
(0.02)\end{array}$ & 0.7 \\
\hline 3.1.2.c Employed (by occupation) & $\begin{array}{r}0.3 \\
(0.34)\end{array}$ & 1.8 & $\begin{array}{r}0.7 \\
(0.25)\end{array}$ & 5.6 \\
\hline 3.1.2.d Average weeks and weekly hours worked & $\begin{array}{r}1.0 \\
(0.06)\end{array}$ & 6.0 & $\begin{array}{r}-0.4 \\
(0.03)\end{array}$ & -3.2 \\
\hline 3.2 Other members & $\begin{array}{r}3.7 \\
(0.34) \\
\end{array}$ & 23.2 & $\begin{array}{r}-0.1 \\
(0.36) \\
\end{array}$ & -1.0 \\
\hline 3.2.1 Employed (by occupation, education, sex and age) & $\begin{array}{r}1.3 \\
(0.39)\end{array}$ & 8.2 & $\begin{array}{r}-0.2 \\
(0.36)\end{array}$ & -1.7 \\
\hline 3.2.2 Average weeks and weekly hours worked & $\begin{array}{r}2.4 \\
(0.36) \\
\end{array}$ & 15.0 & $\begin{array}{r}0.1 \\
(0.01) \\
\end{array}$ & 0.8 \\
\hline $\begin{array}{l}\text { 4. Nonlabor incomes: other nonworking family members } \\
\text { Receiving nonlabor income (by education and sex) }\end{array}$ & $\begin{array}{r}0.7 \\
(0.11) \\
\end{array}$ & 4.2 & $\begin{array}{r}0.9 \\
(0.16) \\
\end{array}$ & 7.0 \\
\hline
\end{tabular}

Standard error in parentheses: Linearized standard errors (Raw Gap), and Delta standard errors (aggregate and detailed effects).

About 37.6 percent of the raw poverty gap was explained by differences in education attainment and the labor-market-related variables of all family members. As a matter of fact, the level of education and labor activity of the family head explained 14.4 percent of the gap, due mainly to fewer weeks and hours worked ( 6 percent) and to an education gap (5.5 percent). The gap in education and the labor activity of other family members explained an 
additional 23.2 percent. In this last case, fewer hours worked (15 percent) appears to be especially important, together with low participation and segregation of those actually employed in low-paid occupations (8.2 percent). An additional 4.2 percent was explained by nonlabor income received by other members of the family (taking into account their education).

Other nonlabor-related factors were crucial in explaining the higher poverty rates of Blacks compared with Whites. In fact, 35.3 percent of the raw gap was explained by differences in demographic characteristics, namely the larger number of dependent children in Black families (13.5 percent), the lower proportion of married couples and higher proportion of femaleheaded families (jointly explaining 11.2 percent), and the generally younger age of family heads (7 percent). The geographical area of residence appears to be irrelevant because the effect of the higher concentration of Blacks in the poorest states was statistically insignificant at 95 percent of confidence; further, it was overcompensated for by the fact that Blacks were more likely to live in the largest metropolitan areas (which, in fact, made a negative contribution to the gap). ${ }^{26}$

Among our other target group, the difference in poverty rates between Hispanics and Whites in 2006 was 12.5 percentage points, and observed family attributes explained a proportion of the raw gap, which was globally similar to the case of Blacks. Indeed, the characteristics effect accounted for 9.5 percentage points (76 percent of the total difference between Hispanics and Whites), resulting in a conditional poverty gap of 3.0 percent (24 percent). Nevertheless, the underlying reasons for higher poverty among Latinos are substantially different from those explaining the higher incidence among Blacks. For example, the sociodemographic characteristics of Hispanics were even more important and explained more than half the overall racial poverty gap (51.9 percent), due mainly to a larger number of dependent children in Hispanic families, accounting for 25 percent, and to their immigration profile, which explained another 15.1 percent. The contribution of young age of family head to explaining the racial poverty gap was similar for Latinos and Blacks (7.1 percent), but not the type of family, which barely contributed 3.2 percent.

Furthermore, achieved education and labor activity among all family members jointly explained about 20 percent of the raw poverty gap, way below the overall contribution of these variables for Blacks. Additionally, the driving factors were also different for the two

\footnotetext{
${ }^{26}$ This result strongly contrasts with the case of African Americans in Brazil, where almost 17 percent of their higher poverty rate compared with Brazilian Whites can be explained by the concentration of Blacks in the poorest states in the north and northeast of the country (Gradín, 2009).
} 
Table 2 Decomposition of the racial poverty gap, 1993, 2001, 2006

\begin{tabular}{|c|c|c|c|c|c|c|c|c|c|c|c|c|}
\hline & \multicolumn{6}{|c|}{ Blacks } & \multicolumn{6}{|c|}{ Hispanics } \\
\hline & 1993 & $\%$ & 2001 & $\%$ & 2006 & $\%$ & 1993 & $\%$ & 2001 & $\%$ & 2006 & $\%$ \\
\hline RAW GAP & $\begin{array}{r}23.0 \\
(0.45) \\
\end{array}$ & 100 & $\begin{array}{r}14.6 \\
(0.31) \\
\end{array}$ & 100 & $\begin{array}{r}15.9 \\
(0.23) \\
\end{array}$ & 100 & $\begin{array}{r}20.7 \\
(0.39) \\
\end{array}$ & 100 & $\begin{array}{r}13.6 \\
(0.29) \\
\end{array}$ & 100 & $\begin{array}{r}12.5 \\
(0.37) \\
\end{array}$ & 100 \\
\hline AGGREGATE COEFFICIENTS EFFECT & $\begin{array}{r}3.5 \\
(0.58)\end{array}$ & 15.4 & $\begin{array}{r}3.8 \\
(0.48)\end{array}$ & 25.9 & $\begin{array}{r}3.7 \\
(0.40)\end{array}$ & 23.4 & $\begin{array}{r}1.7 \\
(0.74)\end{array}$ & 8.2 & $\begin{array}{r}2.5 \\
(0.53)\end{array}$ & 18.5 & $\begin{array}{r}3.0 \\
(0.51)\end{array}$ & 24.0 \\
\hline $\begin{array}{l}\text { AGGREGATE CHARACTERISTICS EFFECT } \\
\text { DETAILED: }\end{array}$ & $\begin{array}{r}19.5 \\
(0.53)\end{array}$ & 84.6 & $\begin{array}{r}10.8 \\
(0.45)\end{array}$ & 74.1 & $\begin{array}{r}12.2 \\
(0.39)\end{array}$ & 76.6 & $\begin{array}{r}19.0 \\
(0.81) \\
\end{array}$ & 91.8 & $\begin{array}{r}11.1 \\
(0.59)\end{array}$ & 81.5 & $\begin{array}{r}9.5 \\
(0.54) \\
\end{array}$ & 76.0 \\
\hline 1. Geographic & $\begin{array}{r}0.3 \\
(0.51) \\
\end{array}$ & 1.2 & $\begin{array}{r}-0.2 \\
(0.36)\end{array}$ & -1.5 & $\begin{array}{r}-0.1 \\
(0.31)\end{array}$ & -0.6 & $\begin{array}{r}-0.2 \\
(0.81) \\
\end{array}$ & -0.8 & $\begin{array}{r}-0.1 \\
(0.36) \\
\end{array}$ & -0.6 & $\begin{array}{r}-0.4 \\
(0.34)\end{array}$ & -2.9 \\
\hline 2. Sociodemographic & $\begin{array}{r}8.5 \\
(0.93) \\
\end{array}$ & 36.8 & $\begin{array}{r}5.2 \\
(0.54) \\
\end{array}$ & 35.3 & $\begin{array}{r}5.6 \\
(0.50) \\
\end{array}$ & 35.3 & $\begin{array}{r}11.9 \\
(0.91) \\
\end{array}$ & 57.7 & $\begin{array}{r}8.1 \\
(0.66) \\
\end{array}$ & 59.8 & $\begin{array}{r}6.5 \\
(0.58) \\
\end{array}$ & 51.9 \\
\hline 3. Education and labor activity & $\begin{array}{r}9.4 \\
(0.76) \\
\end{array}$ & 41.1 & $\begin{array}{r}5.4 \\
(0.41) \\
\end{array}$ & 37.1 & $\begin{array}{r}6.0 \\
(0.38) \\
\end{array}$ & 37.6 & $\begin{array}{r}6.8 \\
(0.59) \\
\end{array}$ & 32.8 & $\begin{array}{r}2.5 \\
(0.49) \\
\end{array}$ & 18.7 & $\begin{array}{r}2.5 \\
(0.40) \\
\end{array}$ & 19.9 \\
\hline 4. Nonlabor incomes & $\begin{array}{r}1.3 \\
(0.31) \\
\end{array}$ & 5.5 & $\begin{array}{r}0.5 \\
(0.13) \\
\end{array}$ & 3.2 & $\begin{array}{r}0.7 \\
(0.11) \\
\end{array}$ & 4.2 & $\begin{array}{r}0.4 \\
(0.21) \\
\end{array}$ & 2.2 & $\begin{array}{r}0.5 \\
(0.16) \\
\end{array}$ & 3.6 & $\begin{array}{r}0.9 \\
(0.16) \\
\end{array}$ & 7.0 \\
\hline
\end{tabular}

Standard error in parentheses: Linearized standard errors (Raw Gap), and Delta standard errors (aggregate and detailed effects).

\section{Conclusions}

In this paper, we have analyzed the gap in poverty rates for ethnic and racial groups in the United States and found that it can largely be explained by family characteristics. We have also

\footnotetext{
${ }^{27}$ Regression estimates for poverty in 1993 and 2001 and more detailed results of the evolution can be found in Gradín (2008).
} 
shown that the main reasons diverge when explaining why Blacks and Latinos are more likely to be poor than Whites. Almost half of what explains the higher poverty of Blacks (37 percent of the overall gap) can be attributed to demographic characteristics, especially a large number of dependent children, family type, and age of the family head. Of similar relevance are education and performance in the labor market, especially low labor market participation by family members other than the family head. On the contrary, in the case of people of Hispanic origin, at least two-thirds of what can be explained (more than half the raw gap) is attributable to the demographic characteristics of families, with even more relevance of the number of children than in the case of Blacks, with a special (even if decreasing) role played by their predominant immigration status, and with the younger age of their family heads being similar in relevance to the case of Blacks. As a consequence of the high employment rates of Hispanic males, labor-market-related characteristics play a less fundamental role than in the case of Blacks, one almost fully accounted for by their larger educational gap. The state or region where minorities live play no role in explaining their higher poverty rates. Further, certain demographic characteristics, including type of family and age of the family head, and other labor variables, e.g., number of hours worked, were shown to have a different impact on the risk of being poor among minorities compared with Whites.

Finally, we have shown that reduction of the racial poverty gap during the 1990s can be fully accounted for by the less important role played by differences in characteristics. Nevertheless, it is important to note that the fact that characteristics accounting for the largest part of the racial poverty gap are vanishing over time does not mean that discrimination is no longer relevant in explaining poverty among minorities in the United States. The poorer characteristics of Blacks and Latinos could be partly the result of different opportunities for access to education and well-paid jobs, and additionally there remain some significant and persistent coefficients effects.

\section{References}

Antecol, H. and K. Bedar (2004), "The importance of labor force attachment differences across Black, Mexican, and White men", Journal of Human Resources, 39 (2), pp. 564-583.

Blank, R. (2002), "Evaluating Welfare Reform in the U.S.", Journal of Economic Literature, 40 (4), pp. 1105-66.

Blinder, A. S. (1973), "Wage Discrimination: Reduced Form and Structural Estimates" Journal of Human Resources, 8 (4), 436-55.

Cappellari, L. and S.P. Jenkins (2004), "Modeling low income transitions", Journal of Applied Econometrics, 19, pp. 593-610.

Carneiro, P., J.J. Heckman and D.V. Masterov (2005), "Labor Market Discrimination and Racial Differences in Premarket Factors", IZA Discussion Paper No. 1453. 
Even, W. E. and D. A. Macpherson (1990), "Plant size and the decline of unionism", Economics Letters, 32 (4), pp. 393-398.

Even, W. E. and D. A. Macpherson (1993), "The Decline of Private-Sector Unionism and the Gender Wage Gap", Journal of Human Resources, 28 (2), pp. 279-296.

Foster-Bey, J.A. Jr (2006), "Did spatial mismatch affect male labor force participation during the 1990s expansion?", in Black males left behind, R. Mincy (Ed.), The Urban Institute Press, pp. 121-146.

Gradín, C. (2008), "Why is poverty so high among Afro-Brazilians? A decomposition analysis of the racial poverty gap", Ecineq Working Paper Series, 2008-96.

Gradín, C. (2009), "Why is poverty so high among Afro-Brazilians? A decomposition analysis of the racial poverty gap", Journal of Development Studies, vol. 45(9), pp. 1-38.

Holzer, J.H., S. Raphael, and M.A. Stoll (2006), "How do employer perceptions of crime and incarceration affect the employment prospect of less-educated young black men?", in Black males left behind, R. Mincy (Ed.), The Urban Institute Press, pp. 67-85.

Iceland, J. (2006), Poverty in America, $2^{\text {nd }}$ edition, University of California Press.

MacLanahan, S. (2007), "Single mothers, fragile families", in Ending poverty in America, J. Edwards, M. Crain, M. and A.L. Kalleberg, The New Press, pp. 77-87.

Oaxaca, R. L. (1973), "Male-female Wage Differentials in Urban Labor Markets", International Economic Review, 14 (3), 693-709.

Rodgers, H.R. (2006), American poverty in a new era of reform", $2^{\text {nd }}$ edition, M.E. Sharpe.

US Census Bureau (2007), "Income, Poverty, and Health Insurance Coverage in the United States: 2006", Current Population Reports. Washington D.C.: US Government Printing Office.

US Census Bureau (2008), "Hispanic Population of the United States", Ethnicity and Ancestry Branch Population Division. Washington D.C.: US Government Printing Office.

US Department of Justice Office of Justice Programs (2007), "Prison and Jail Inmates at Midyear 2006", Bureau of Justice Statistics Bulletin, June. Washington D.C.: US Government Printing Office.

US Department of Health and Human Services (2004), "Trends in the Well-Being of America's Children and Youth 2003", Office of the Assistant Secretary for Planning and Evaluation. Washington D.C.: US Government Printing Office.

Yun, M-S. (2004), "Decomposing Differences in the First moment", Economics Letters, 82 (2), pp. 275280.

Yun, M-S. (2005), "A Simple Solution to the Identification Problem in Detailed Wage Decompositions", Economic Inquiry, 43 (4), pp. 766-772.

Yun, M-S. (2008), "Identification Problem and Detailed Oaxaca Decomposition: A General Solution and Inference", Journal of Economic and Social Measurement, 33 (1), pp. 27-38. 
APPENDIX

\begin{tabular}{|c|c|c|c|c|c|c|}
\hline \multirow{2}{*}{$\begin{array}{l}\text { Logit coefficients of the } \\
\text { probability of being poor in } 2006 \\
\text { New England }\end{array}$} & \multicolumn{2}{|l|}{ Whites } & \multicolumn{2}{|l|}{ Blacks } & \multicolumn{2}{|c|}{ Hispanics } \\
\hline & -0.082 & (.10) & -0.729 & $(.30)$ & 0.205 & $(.22)$ \\
\hline East North Central & -0.236 & (.09) & 0.053 & $(.17)$ & -0.407 & (.18) \\
\hline West North Central & -0.103 & (.10) & -0.177 & $(.22)$ & 0.027 & $(.21)$ \\
\hline South Atlantic & -0.262 & (.09) & -0.219 & $(.16)$ & -0.128 & (.15) \\
\hline East South Central & 0.140 & (.11) & 0.001 & $(.20)$ & 0.160 & (.29) \\
\hline West South Central & -0.135 & (.10) & 0.226 & (.18) & 0.259 & (.14) \\
\hline Mountain & -0.394 & (.10) & -0.150 & $(.25)$ & -0.088 & (.16) \\
\hline Pacific & -0.372 & (.10) & -0.489 & $(.21)$ & -0.304 & (.13) \\
\hline non metropolitan area & 0.468 & (.09) & 0.376 & (.17) & 0.196 & (.14) \\
\hline $0.1-0.25$ million inhabitants & 0.205 & (.11) & -0.037 & (.23) & 0.103 & (.15) \\
\hline $0.25-0.5$ million inhabitants & 0.224 & (.10) & 0.184 & (.18) & -0.066 & (.15) \\
\hline $0.5-1$ million inhabitants & 0.000 & (.11) & 0.116 & (.18) & 0.089 & (.13) \\
\hline 1-2.5 million inhabitants+ & 0.071 & $(.10)$ & 0.044 & $(.15)$ & -0.060 & $(.12)$ \\
\hline 2.5-5 million inhabitants+ & 0.093 & $(.10)$ & -0.096 & $(.16)$ & -0.273 & (.12) \\
\hline Family: female-headed married couple & -0.102 & $(.16)$ & 0.239 & $(.25)$ & 0.027 & $(.18)$ \\
\hline Family: Male (no spouse) & 0.705 & (.10) & 0.490 & (.19) & 0.431 & (.14) \\
\hline Family: Female (no spouse, no children) & 1.036 & $(.10)$ & 0.975 & $(.18)$ & 0.668 & $(.15)$ \\
\hline Family: Female (no spouse, with children & 1.179 & $(.14)$ & 0.687 & $(.22)$ & 0.764 & (.17) \\
\hline Head: Native, foreign parents & -0.160 & (.10) & -0.099 & $(.27)$ & -0.005 & (.11) \\
\hline Head: Naturalized American & -0.121 & (.14) & 0.107 & $(.23)$ & -0.003 & (.12) \\
\hline Head: Foreigner & 0.191 & (.16) & 0.454 & $(.20)$ & 0.514 & (.10) \\
\hline Head: moved within same county & 0.459 & $(.08)$ & 0.317 & $(.13)$ & 0.293 & (.12) \\
\hline Head: moved from different county & 0.367 & (.10) & 0.404 & $(.20)$ & 0.176 & (.16) \\
\hline Head: employed lone-mother & -0.179 & (.15) & 0.103 & $(.22)$ & 0.115 & (.19) \\
\hline Head: $25-55$ years old & -0.825 & $(.07)$ & -0.273 & (.14) & -0.069 & (.11) \\
\hline Head: $56+$ years old & -2.350 & (.09) & -1.515 & $(.17)$ & -0.653 & (.15) \\
\hline Head: secondary education & -0.323 & $(.07)$ & -0.362 & $(.11)$ & -0.407 & $(.09)$ \\
\hline Head: College & -0.627 & $(.07)$ & -0.822 & $(.12)$ & -0.826 & (.10) \\
\hline Head: inactive & -0.285 & $(.14)$ & -0.170 & $(.23)$ & 0.008 & (.17) \\
\hline Head: unemployed & 0.495 & (.15) & 0.730 & $(.24)$ & 0.622 & $(.20)$ \\
\hline Head: $p v, m p$ & -0.392 & (.14) & -0.472 & $(.20)$ & -0.280 & (.18) \\
\hline Head: pv, p-t, nc & 0.764 & (.12) & 0.615 & (.18) & 0.757 & (.14) \\
\hline Head: $\mathrm{pb}, \mathrm{mp}$ & -0.256 & (.18) & -0.438 & $(.36)$ & -1.180 & (.35) \\
\hline Head: $p b$, non $m p$ & 0.364 & (.20) & -0.326 & $(.21)$ & 0.057 & $(.24)$ \\
\hline Head: self-employed & 0.494 & (.13) & 0.186 & (.30) & 0.221 & (.18) \\
\hline Head: No. of weeks worked & -0.048 & $(.00)$ & -0.046 & $(.00)$ & -0.037 & $(.00)$ \\
\hline Head: No. of hours worked & -0.017 & $(.00)$ & -0.019 & $(.00)$ & -0.016 & $(.00)$ \\
\hline No. children below 10 years old & 0.463 & (.04) & 0.585 & $(.07)$ & 0.418 & $(.05)$ \\
\hline No. children $10-15$ years old & 0.288 & (.05) & 0.477 & $(.07)$ & 0.491 & $(.06)$ \\
\hline No. dependents $16-45$ years old & 0.566 & $(.05)$ & 0.536 & (.08) & 0.469 & $(.06)$ \\
\hline No. dependents $46-64$ years old & 1.366 & (.10) & 0.907 & (.16) & 0.613 & (.14) \\
\hline No. dependents $65+$ years old & 1.904 & (.16) & 1.224 & (.24) & 0.230 & $(.21)$ \\
\hline No. other employed, $15-45$, primary & -0.234 & (.20) & -0.252 & (.33) & -0.332 & $(.18)$ \\
\hline No. other employed, $15-45$, secondary & -0.378 & (.18) & -0.408 & (.30) & -0.387 & (.19) \\
\hline No. other employed, $15-45$, College & -0.730 & (.18) & -1.506 & (.37) & -0.832 & (.23) \\
\hline No. other employed, $46+$, primary & -0.779 & (.55) & 0.108 & $(.46)$ & -0.492 & $(.27)$ \\
\hline No. other employed, $46+$, sec-College & -0.849 & (.14) & -1.062 & (.31) & -1.043 & $(.22)$ \\
\hline No. other employed, $\mathrm{pv}, \mathrm{mp}$ & -0.468 & (.15) & -0.387 & (.28) & -0.416 & $(.26)$ \\
\hline No. other employed, pv, f-t, non mp & -0.161 & (.11) & -0.283 & (.18) & -0.247 & (.14) \\
\hline No. other employed, pv, p-t, non mp & 0.138 & (.14) & 0.215 & (.22) & 0.248 & (.17) \\
\hline No. other emplo & -0.500 & (.21) & -2.029 & (.51) & -0.593 & $(.40)$ \\
\hline No. other employed, pb, non mp & -0.912 & (.25) & -0.492 & $(.29)$ & 0.070 & $(.33)$ \\
\hline No. other self-employed, & 0.472 & (.15) & 0.039 & (.38) & 0.608 & $(.23)$ \\
\hline No. of other female employed & 0.266 & (.16) & 0.473 & $(.23)$ & 0.388 & $(.16)$ \\
\hline Weeks worked by others & -0.035 & (.01) & -0.020 & (.01) & -0.031 & $(.01)$ \\
\hline Hours worked by others & -0.008 & (.01) & -0.020 & (.01) & -0.008 & $(.01)$ \\
\hline No. other nonlabor income, primary & -0.364 & (.16) & -0.259 & (.19) & -0.583 & $(.16)$ \\
\hline No. other nonlabor income, secondary & -0.787 & (.17) & -1.058 & $(.23)$ & -1.131 & $(.28)$ \\
\hline No. other nonlabor income, College & -0.805 & (.19) & -0.948 & $(.24)$ & -0.683 & $(.23)$ \\
\hline N. other income female receivers & -0.135 & (.17) & -0.330 & $(.23)$ & -0.391 & $(.20)$ \\
\hline Constant & 0.669 & (.21) & 0.890 & (.36) & 0.295 & $(.28)$ \\
\hline No. of unweighted observations & 132,853 & & 23,840 & & 34,125 & \\
\hline Pseudo $\mathrm{R}^{2}$ & 41.6 & & 46.4 & & 37.9 & \\
\hline Wald $\chi^{2}(60)$ & 4,089 & & 1,305 & & 1,628 & \\
\hline Probability $\left(>\chi^{2}\right)$ & 0.0 & & 0.0 & & 0.0 & \\
\hline
\end{tabular}

Notes: Robust standard errors in parenthesis. Observations are all individuals with full information, clustered by family. Abbreviations: $p v=$ private sector, $p b=$ public sector, $p$-t=part-time, $f-t=f u l l-$ time, $p=$ managerial or professional occupation. Poverty regressions for 1993 and 2001 omitted for the sake of presentation (see Gradín, 2008). 